\title{
X. Notice of Mr. Pritchard's gradula progress in the application of iron to the erection of bridges
}

\author{
John White Esq.
}

To cite this article: John White Esq. (1832) X. Notice of Mr. Pritchard's gradula progress in the application of iron to the erection of bridges , Philosophical Magazine Series 2, 11:62, 81-82, DOI: $10.1080 / 14786443208647687$

To link to this article: http://dx.doi.org/10.1080/14786443208647687

2009.

Submit your article to this journal $₫$

Џll Article views: 2

Q View related articles $\square$ 


\title{
ANNALS OF PHILOSOPHY.
}

\author{
[NEW SERIES.]
}

$F E B R U A R Y 1832$.

X. Notice of Mr. Pritchard's gradual Progress in the Application of Iron to the Erection of Bridges. By JoHN W HITE, Esq.

[With a Plate.]

THE interest which $I$ feel in recording the advancement of

Science, and the respect which I entertain for the memory of my maternal grandfather, Mr. Thomas Farnolls Pritchard, first of Shrewsbury, and then of Eyton Turret, Shropshire, have induced me draw out (as far as recollection and the materials in my possession enable me) a brief account of part of the consecutive designs which led to the first application of cast iron for arches in the construction of bridges; an application which not only originated with him, but of which the principle has subsequently been applied in numerous works of magnitude and importance, to the great advantage of the public.

In the year $1773 \mathrm{Mr}$. Pritchard was engaged in making a design for Stourport bridge, where the Severn requires a water-way sufficient to permit a rise, in flood-times, of 18 feet, and an aperture of at least 136 feet. He originally meditated the construction of a Timber bridge, similar to that which then crossed the Thames at Walton: but not being satisfied with the material, and at the same time being unwilling to employ brick or stone in the buttresses of the bridge in such a manner as would impede the current, he made his first design for a brick bridge on an iron centre, lightened in the buttresses and in part over the arch, by circular perforations, which would allow a passage for the water.

Apparently dissatisfied with this arrangement, he planned various bridges of these mixed materials; till at length, encouraged by the patronage of the spirited Iron-masters of Colebrook Dale, he made a design for the bridge now exist-

* Communicated by the Author.

N.S. Vol. 11. No. 62. Feb. 1832. 


\section{Notice of the Arrival of Twenty-six of the Summer Birds}

ing near that place, the execution of which was commenced in the year 1778 , when he died.

I have understood that his labours encountered many impediments; but the high estimation entertained for him in the county of Salop enabled him to overcome them. The late $\mathrm{Mr}$. John Wilkinson, Mr. Darby, Mr. Onions, and others, (though the establishment of their new iron-works called for the employment of a large capital,) did not hesitate to forward hisoperations or to promote the completion of the Colebrook Dale bridge, which, with the inn on the west side, was paid for by a tontine.

The annexed reduction of his designs will elucidate the gradual development of his ideas in 1774 \& 1775.-See Plate I.

[To be continued.]

XI. Notice of the Arrival of Tiventy-six of the Summer Birds of Passage in the Neighbourhood of Carlisle, together with some of the scarcer Species that have been met with in the same Vicinity during the Year 1831; with Observations, \&c. By A Correspondent.

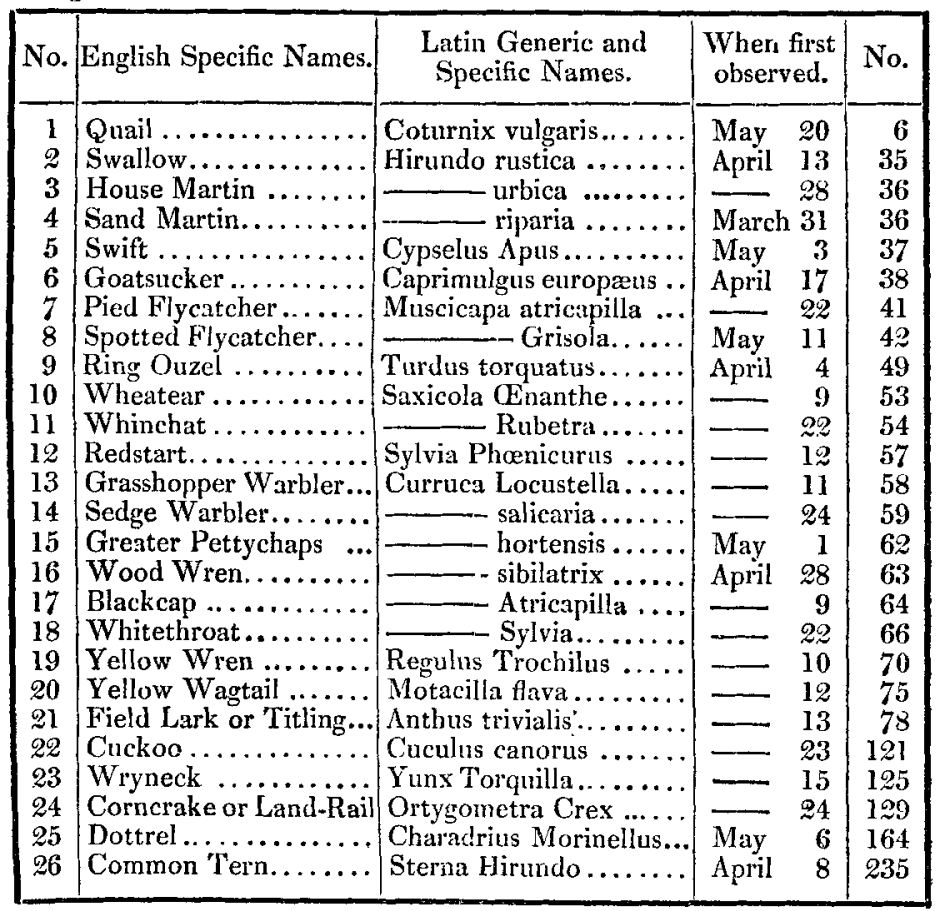

Note.-The figures contained in the column on the right in the above Table, as well as those affixed to the species not included in it, refer to the numbers 


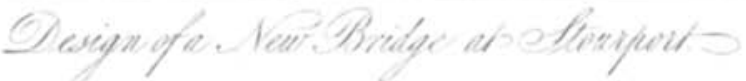

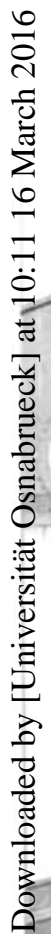

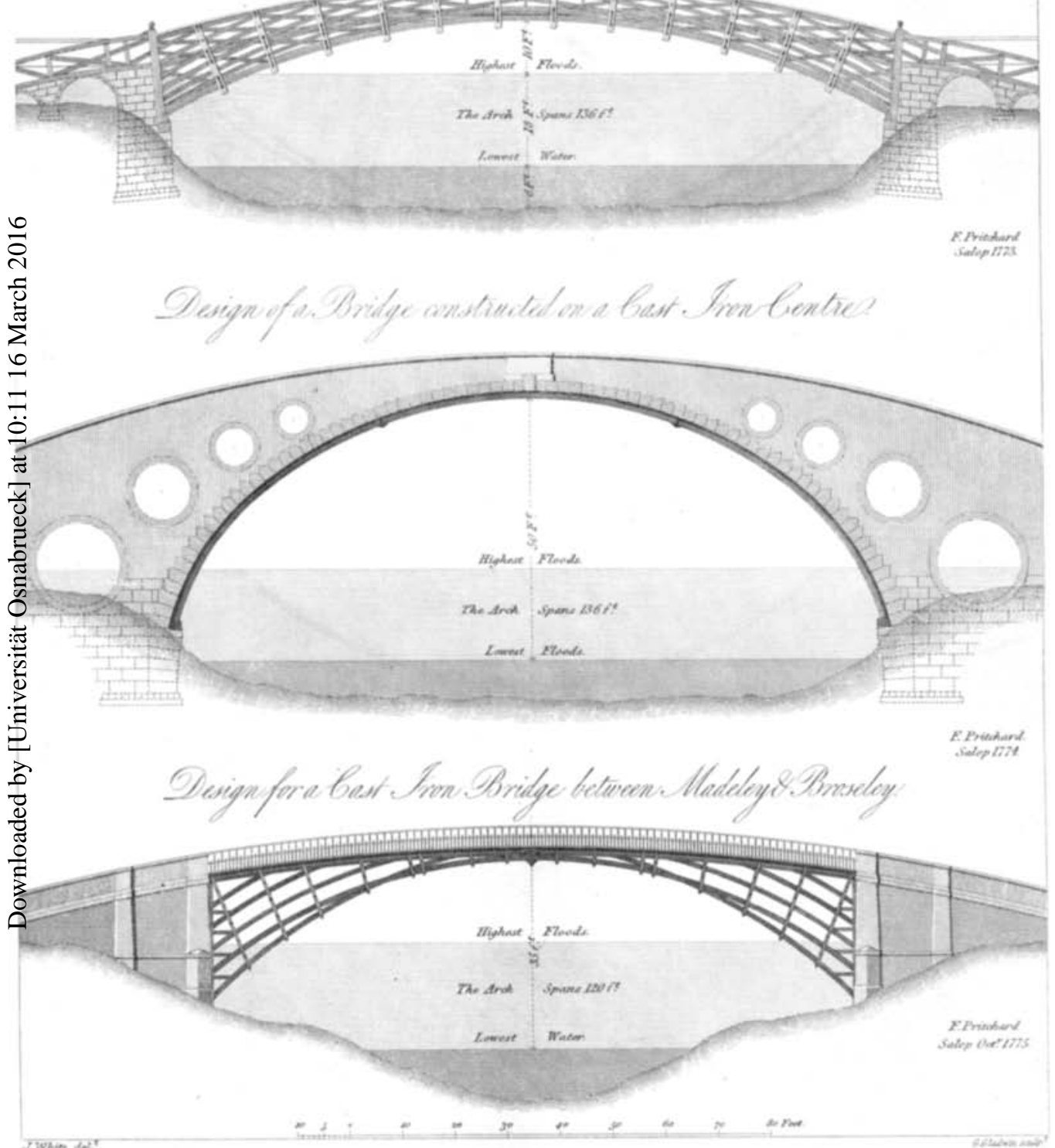

